\title{
NGHIÊN CỨU TRƯỜNG HỢP VỀ CÁCH GIÁO VIÊN LÀM VIỆC VỚI TRẺ EM CÓ HOÀN CẢNH ĐẠC BIẸTT TRONG LỚP HỌC
}

A case study of regular teachers handling children

with special needs in general education classrooms

Ngày nhận bài 01/9/2016; ngày phản biện: 15/10/2016; ngày duyệt đăng: 21/11/2016

\section{Emmie Manliguez Cabanlit*}

\section{TÓM TẮT}

Chính phủ Philippines thực hiện chính sách giáo dục tổng thể nhằm tăng tỷ lệ học sinh đến trường. Một trong những phần của chương trình đó là việc bố trí các trẻ em có hoàn cảnh đặc biệt vào các lớp học bình thường khác nơi mà các em học theo cặp/nhóm dưới sự hướng dẫn của giáo viên. Bài viết này là một nghiên cứu trường hợp về hai giáo viên về sự sẵn sàng của họ trong việc tiến hành giáo dục tổng thể, những khó khăn, sự thay đổi chương trình, và sự thích nghi trong việc giáo dục học sinh có hoàn cảnh đặc biệt. Bài viết cũng đề xuất một số giải pháp để nâng cao hiệu quả của việc áp dụng giáo dục tổng thể. Cách nghiên cứu trường hợp được vận dụng trong nghiên cứu này cùng với việc sử dụng các nguồn dữ liệu. Cụ thể, 2 giáo viên được lựa chọn để phỏng vấn từng người một theo cách phỏng vấn nhóm. Kết quả phân tích dữ liệu cho thấy rằng sự chủ động sẵn sàng của giáo viên là cốt lõi trong giáo dục tổng thể. Họ thừa nhận cảm giác không thoải mái trong việc tiếp xúc với học sinh có hoàn cảnh đặc biệt liên quan đến các vấn đề vệ sinh thân thể. Các giáo viên cũng bày tỏ gánh nặng trong việc giáo dục các học sinh này với các vấn đề về ứng xử và hành vi vì điều này sẽ ảnh hưởng đến gián đoạn lớp học. Các kỹ năng cần thiết trong tiếp xúc với các trẻ em có hoàn cảnh đặc biệt cần phải có. Điều này thúc đẩy các giáo viên trong việc thay đổi chương trình như tổ chức cho các em các hoạt động khác nhau và đơn giản cùng với các trẻ em bình thường khác. Bởi vậy, bài viết này đưa ra một giải pháp đó là thiết lập các khóa đào tạo tại chức cho các giáo viên những người đã được đào tạo theo chương trình cũ, trang bị các kỹ năng để giảng dạy giáo dục tổng thể và đặc biệt họ có khả năng điều chỉnh chương trình trong việc giảng dạy trẻ em có hoàn cảnh đặc biệt.

Từ khóa: Giáo viên phổ thông; giáo dục tổng thể; trẻ em có hoàn cảnh đặc biệt; thay đổi chuoong trình

\begin{abstract}
The Philippines implements Inclusive Education as a strategy to increase participation rate of children in school. One of the program options in this implementation is the placement of children with special needs (CSN) in regular or general education classrooms where the child learns with his/her peers under the regular teacher who addresses the child's needs. This paper is a case study of two regular teachers in such a situation which is aimed at exploring their readiness for inclusive education, their challenges and curricular modifications and/or adaptations in addressing CSN. It also determined some ways to improve the implementation of inclusive education. A case study approach
\end{abstract}

\footnotetext{
* Ph.D. - University of Southeastern Philippines (USeP), Davao City, Philippines
} 
was utilized in the conduct of this study, utilizing informative and contextual data. In particular, two teachers were purposely involved in a one-on-one interview followed by a focus group discussion (FGD). Through thematic analysis, it is revealed that the readiness of teachers was centered on the concepts and beliefs on inclusive education. They acknowledged the feeling of being awkward and uncomfortable in handling children with special needs for some hygienic problems like salivating and excessive sweating. They also expressed a burden on handling children with behavioral problems because it disrupts classes. The essential skills necessary in handling children with special needs is wanting. This prompted the teachers to make some curricular modifications like giving a child different but simplified activities from the regular children. Hence, this study recommends that more in-service trainings be given for teachers who took up their education degree in the old curriculum so that their capacity in handling inclusive classes will be enhanced and they would be able to give appropriate curricular modifications to children with special needs.

Keywords: generalist teachers/classroom, inclusive classes/education, children with special needs, curricular modifications

\section{Introduction}

The interest of educating the Filipino children can be traced back in the history of the country in 1902, when Fred Atkinson, an American Director of Education in the Philippines, gave orders to the Secretary of Public Instruction in the country to enroll the blind and deaf children in the general classroom like any regular child (Quijano, 2007). It paved the way to the creation of Special Education in 1907, where it grew nationwide. Schools and centers were opened in public and private schools in order to accommodate children with special needs (CSN). However, according to DepEd Order No. 72, s. 2009, only $2 \%$ of the over two million children with disabilities were served by the Special Education Schools at present, and this shows a very low rate of participation. Because of this, the Philippines implementsInclusive Education as a strategy to increase participation rate of children in school. One of the program options in this implementation is the placement of CSN in regular or general education classrooms where the child learns with his/her peers under the regular teacher who addresses the child's needs.

The mandate of Inclusive Education was underscored by DepEd Order No. 72, series 2009, calling all schools to be inclusive in nature. It defines Inclusive education as, "embraces the philosophy of accepting all children regardless of race, size, shape, color, ability or disability with support from school staff, students, parents and the community". Internal and external stakeholders of the school community areencouraged to support the appropriate education of any child. Further, it is embodied in the Salamanca Statement and framework for Action on Special Needs Education, 1994 that ,"Regular schools with this inclusive orientation are the most effective means of combating discriminatory attitudes, creating welcoming communities, building and inclusive society and achieving education for all; moreover, they provide an effective education to the majority of children and improve the efficiency and ultimately the costeffectiveness of the entire education system."With these issuances, every child is given equalaccess and opportunity to 
beenrolled in any school and be taken careof bygeneralists or regular teachers in the general education classrooms.

An inclusion strategy, not only in the Philippines but throughout global education, is a very good option for providing an environment of belongingness to children with special needs. However, the success of this inclusion lies on the preparedness of the regular teachers in handling children inside general education classrooms. Tornillo (1994), the president of the Florida Education Association United, stressed so much concern that this strategy would leave many classroom teachers without resources, support and proper training that consequently boils down to inappropriate education for the disabled children and give disruptions to the education of regular children.

On the other hand, a study on Teachers' Experience with Inclusive Education in Singapore (Yeo, Chong, Neihart\&Huan, 2013), revealed that the most critical factor associated with successful inclusion is the positive attitude of teachers. However, the study revealed that there are more negative than positive experiences of teachers in implementing inclusion. One of the identified negative experiences of teachers is being stressed from a challenging behavior of children and instructional difficulty in accommodating the needs of diverse children in a regular classroom. Even then, teachers were found to be satisfied in the progress of their students and acquiring new learning for themselves.

Further, as cited by Takahaski (2013) in his paper abstract on the Suggestions for a Teacher Training Program for Inclusive Education in a Japanese University, he pointed out that general education teachers are facing problems in relating to children with disabilities. Because of this, he proposed to have a review of training programs for teachers in handling inclusive education as well as reviewing some attachment theories focusing on teacher-child relationships.

In the Philippines, inclusion was started many years ago. But according to the study conducted by the Australian Agency for International Development (AusAID) on identifying barriers to inclusion of Children with Disability in the Philippines presented by Jason Alinsunurin (2012) on a forum, the findings revealed that there is still much needs to be done for effective implementation of inclusive education in the country. This we could say, that the success of this inclusion generally depends on the knowledge, skills, attitude and acceptance of the regularteachers who are the key providers of learning in the general classroom where it is said to be a home for every child.

This study is anchored on the Practical Theory of Marland and Osborne (1990), which said that every teacher has his practical way in handling the classroom situation based on her knowledge, values and experiences which are relevant to practical teaching. This characteristic of a teacher is a strong determining factor in setting the context of the day-to-day instruction in the teaching experiences. Inclusive education, according to the European Agency for Development in Special Needs Education (2001), “depends on what teachers do in the classroom. The way in which the teachers realize inclusion within classroom can take any form." The teacher as the major actor in the drama of education is believed to possess some degree of essentials in the disposal of his service to the children of today. 


\section{Objectives}

The institutionalized inclusion of disadvantaged children in the regular classrooms from 2009 up to the present has got a lot of benefits. According to the report made by Quijano (2011), the former Undersecretary of Programs and Projects, DepEd-Philippines, inclusive education creates positive social interaction between regular and CSN. This social benefit reduces and eliminates prejudices among disadvantaged children which resulted to improve self-concept and self-esteem among these children. However, she mentioned a challenge that "inclusion may result in overcrowding and lowering of quality of education." Somehow, regular teachers in the general classrooms have varied experiences in handling children with special needs in the delivery of general education.

This case study aimed to explore the readiness of general teachers for handling inclusive classes, their challenges and curricular modifications and/or adaptations in addressing CSN.It also determined some ways to improve the implementation of inclusive education in the country.

\section{Assumption}

The teachers' belief and orientation about inclusive education enabled them to accept children with special needs in the general classrooms and handle them based on their practical knowledge and experiences relevant to the perceived child's needs.

\section{Method}

\section{Research Design}

This study employed a qualitative design to explore the readiness, challenges and modifications made by the regular teachers in handling CSN in general education classrooms. It made use of a case study approach. A case study approach enables one to come up with a simplified understanding how individuals handle a specific bounded situation, utilizing informative and contextual data (Creswell, 2006).

\section{Participants and Sampling}

Two regular teachers were purposely selected as participants of the study. These teachers have served at least two years in handling children with disabilities in an inclusive classroom. Teachers who have taught for two years are not so neophyte in doing his job and already gainedsome skills in classroom management.

\section{Research Instruments and Data Analysis}

It made use of a one-on-one interview of the participants and a focus group discussion to validate some of the answers. Their answers during the interview were recorded in audio while answers during FGD were documented in written form.Data gathered through a oneon-one interview were transcribed, contextually organized and a thematically analyzed. Comments from a parent and document analysis (lesson plan) were considered inputs for some triangulations. However, data coming from the supervisors' observation concerning inclusive classrooms became a limitation to this effect.

\section{Ethical Protocols}

The data gathered in this study has gone some procedural steps. However, to preserve the confidentiality of the data, identity of school and the participants, as well as the identity of disadvantaged children under their care are not mentioned in this study. 


\section{Results and Discussions}

There are models of inclusion for children with special needs. In the advent of DepEd Order No.72, s. 2009, the implementation of inclusive education in the Philippines generally used two major models, namely: 1) the partial mainstreaming, where the CSN are educated in the general classes for only a certain period and be given additional help or specialized services by a SPED teacher; and 2) the full mainstreaming, where the CSN are placed completely in a general classroom and receive special services with regular teachers.Recently, the Department of Education in the Philippines implements the approved Rationalization Programon November 15, 2013 under Executive Order 336 s. 2004 (DepEd Order NO. 50, s. 2013). Bureaus were created under this program and placing Inclusive Education under the Curriculum Development Bureau, of which it emphasized mainstreaming, thus, it only requires adaptations and modifications of learning environment and curriculum for children with special needs (Sec.1 \& 2, Special Education Act of 2008). The discussions on this study centered on the full mainstreaming model where teachers got varied experiences in handling children with special needs.

\section{Experiences of Regulars Teachers handling CSN in General Classrooms}

Both teachers acknowledged that there was an orientation given about the concepts of inclusive education but not on the handling of children with special needs. They believed that in an inclusive education, no child is refused for enrolment, that every child is welcome in the regular classroom regardless of background and disability.

During the focused group discussion, the teachers acknowledged the feeling of being awkward and uncomfortable in handling CSN for some hygienic problems like salivating and excessive sweating. They also expressed their burden on handling children with behavioral problems because it disrupts classes and it is patience-testing. One of the teachers said, when she is irritated, she just took a deep breath and moved a distance. This finding is supported by the (Yeo, Chong, Neihart\&Huan, 2013), who said that one of the identified negative experiences of teachers is being stressed from a challenging behavior of children and difficulty in accommodating the needs of diverse children in a regular classroom.

One of the teachers expressed her difficulty in managing the behavior of the child with special needs to the point of calling the mother inside the classroom and sits beside the child during classes to help her control the child who seemed to roam around the room at times. During the written activity, when the child submits an output, she gave stars as rewards. She simplified the activities at the child's reach.

On the other hand, the other teacher said that she gave the child a different activity so it would refrain him from getting trouble with his classmates. She also said that for a child with hearing impairment, she has to repeat the instructions given and at times she has to write the instructions on paper. She also put the child in front of a row and when he moves around, he is reprimanded like a regular child. She has also assigned a classmate of him to watch him closely while doing an activity.

In terms of using resources inside the classroom, the teachers used the k-12 activity sheets that develop psychomotor skills, flashcards for reading, clay for molding and microphone for speech development. While 
for the teacher with a hearing impaired child, she just gave some simple and common sign languages.

The teachers both acknowledged that they promoted respect and tolerance in the classroom by not labeling on any disability although they were given simplified activities. Besides, they were also given opportunities such as joining in scout camping with the presence of the mother.

\section{Readiness of Regulars Teachers}

\section{handling CSN in General Classrooms}

The teachers' readiness in handling CNS in general classrooms is centered on the concept and beliefs about inclusive education. They understood that inclusive education accepts all children regardless of background and disability. They also believed that no child is deprived of his education. Because of this, they are ready to accept anyone who comes for enrollment without further questions or refusal. Their classroom becomes a home for every child that seeks education. This findings confirmed the statement of Dapudong (2013), who said that " ...public primary school teachers had a favorable attitude towards inclusion of LD children in regular classrooms in terms of their beliefs, feelings and actions." She added that a more training and qualification advancement program be opened up for them to improve their knowledge and attitude.

On classroom management, they were simply aware of the classroom resources available for the child's utilization in a simplified activity. They used the k-12 activity sheets that develop psychomotor skills, flashcards for reading, and clay for molding and microphone for speech development. This means they know how to use in some practicalways the resources within their reach to provide simplified activities for children with special needs.

However, it is remarkable to note that in the general classrooms, promotion of respect and tolerance is advocated. One of the teachers said that she even allowed the child to sleep after recess time to take a rest from his usual routine. Both teachers and students practiced the 'no labeling' of disability and as much as possible. The teachers understanding of inclusive education will be the one to shape his way in handling CSN (Piyao, 2012). Although different and simplified activities were sometimes given, they tried to treat them in a regular manner.

\section{Challenges and Curricular Modifications or Adaptations \\ Challenges refer to the some difficulties} and concerns encountered by general teachers in handling CSN. Modifications refer to "curricular adaptations which change or lower expectations or standards (Fennel, 2013). Adaptations make accommodations for special education students to access or obtain an opportunity with general students in the learning environment without lowering the standards of the curriculum. This portion presents the challenges and curricular modifications or adaptations met by the teachers in handling CSN in general classrooms.

On skills. The big challenge met by the teachers was on the wanting of skill for handling children with disability. One of the respondents humbly accepted that she has no idea how to handle the child with special needs. While the other teacher said she has a little idea to handle not because of training but because of her experience from her own child. This simply means that teachers used practical 
and relevant experiences in accommodating children with special needs.These findings come in congruence with the report ofTornillo (1994) that inclusive education might leave the teachers stressed to do the job and give inappropriate handling to CSN.These challenges made them to adapt some defensive moves such that at the beginning of the school year, they already informed the parents not to expect much from them to handle the child properly according to his disability. In fact, they provided a formduring enrollment which parent could indicate the presumed disability of the child as basis for giving more attention.However, one parent said during an interview that she was already aware of this fact and that she did not expect much learning academically but rather on the social progress of her child. This is in consonance with the report of Downing \&Hardimas cited by Kimbrough \&Mellen(2012), that in inclusive education, some parents of children with disabilities did not expect so much mastery on the competency of the general curriculum but rather on the social benefits gained by the children such that they become happier and motivated to go to school.

Attitude and acceptance. At the start of the year, teachers felt the discomfort to see the behaviors of CSN. The respondents mentioned two problems that posed a challenge for acceptance. These are problems related to hygiene such as salivating and excessive sweating, and child's disruptive behavior. On salivating, the teacher taught the child the basic care for his mouth with a constant follow up and checking both at home and in school. She has to hug the child to make him conscious of his smell. While the other teacher acted as more than a 'yaya' to remove excessive sweating by the use of a towel which are always available in his bag. To minimize the disruptive behavior of the child, one of the teachers allowed the mother to sit beside the child inside the classroom during classes, while the other teacher asked the help a classmate to watch closely with the child.

Classroom management. One of the teachers faced difficulty in controlling the behavior of the child, moving from one place to the other causingtrouble inside the classroom. This behavior prompted the whole class to complain about him. According to her, if only she could have the idea how to handle this kind of behavior, she would have not met this kind of crisis. She dealt this problem by letting the mother came into her class for the whole day to watch over the child's misbehavior. This made her found relief somehow on the burden of attendingthe child more often. This finding is supported by the paper of Takahaski (2013), who affirmed that general education teachers are facing problems in relating to children with disabilities. On curricular implementations, the teacher has difficulty in enabling the child to write. She addressed this attitude by employing simple reward system just to encourage the child to finish the written activity. She also gave him a simplified differentiated activity from other regular students based on what she perceived to the disability of the child. However, these modifications were not plainly stated in her daily lesson plan, but she allowed flexibility and practicality to attend to the needs of child.

On the other hand, another teacher incurred a challenge on instructing a child with hearing impairment. She put the child in front of the row and repeated the instructions more often. At other times, she had to write the instructions on paper. Since she had an 
experience with her own child, she was able to use some common sign language that she learned contextually.

\section{Findings}

1. The readiness of regular teachers handling CSN in general classrooms is centered on the knowledge, particularly on the concepts and beliefs about inclusive education. Because of this awareness, they advocated respect and tolerance among inside the classroom.

2. Their challenges lie on the wanting of skill in handling each disability, attitude and acceptance on the behavior of CSN in the general classroom, and a difficulty of classroom management when a certain behavior of a CSN disrupts the general students.

3. Adaptations and curricular modifications are made by the regulars teachers based on their practical knowledge and experiences relevant to the perceived disability.

\section{Conclusions}

Although the implementation of inclusive education is already a part of the system, the findings above would point out to a statement that regular teachers handling $\mathrm{CSN}$ in the general education classrooms are still wanting a thorough skill training on handling specific disability for a more satisfying need response to CSN without sacrificing the education of the general education students. Knowledge coupled with skills and attitude for handling CSN will effectively enable the regular teachers to make some adaptations and curricular modifications for a more meaningful implementation of inclusive education in the country.

\section{REFERENCES}

1. Alinsunurin, J. (2012). LCDPFI Conducts Forum on Inclusive Education in the Philippines. Retrieved: http://lcdphilippinesfoundation.org/news/lcdpfi-conducts-forum-on-inclusiveeducation-in-the-philippines-2.

2. Creswell, J. W. (1998). Qualitative inquiry and research design: Choosing among five traditions. Thousand Oaks, CA: Sage.

3. Creswell, J. W. (2006). Research design: Qualitative, quantitative, and mixed methods approaches(2nd ed.). Thousand Oaks, CA: Sage.

4. Dapudong, R. (2013). Knowledge and Attitude towards Inclusive Education of Children with Learning disabilities: The Case Thai Primary School Teachers.ISSN-L: 2223-9553, ISSN: 2223-9944 Vol. 4 No. 4 July 2013Academic Research International. Retrieved: www.journals.savap.org.pk

5. Fennel, Zachary (2013).Adaptations, Accommodations, and Modifications. Retrieved: http://www.specialeducationguide.com/pre-k-12/inclusion/adaptations-accommodations and-modifications.

6. Jalotjot, E., et al (2013). Is your School Inclusive?- A Preliminary Survey of Selected SPED Centers in Southern Philippines. USEP, Philippines.

7. Jalotjot, E., et.al (2010). Evaluation of the Performance of SPED Teachers on Their Role in the Implementation of Inclusive Education. USEP, Philippines. 
8. Holdheide and Reschly, (2008).Teachers' Preparation to Deliver Inclusion Services to Students with Disabilities. Retrieved: http://tgsource.org

9. Kimbrough, R., \&Mellen, K. (2012).Research summary: Perceptions of inclusion of students with disabilities in the middle school. Retrieved [date] from http://www.amle.org/TabId/198/ArtMID/696/ArticleID/308/Research-SummaryPerceptions-of-Inclusion-of-Students-with-Disabilities.aspx

10. Lay See Yeo ${ }^{a^{*}}$, Wan HarChong ${ }^{a}$, Maureen F. Neihart ${ }^{\mathrm{a}} \&$ Vivien S. Huan ${ }^{\mathrm{a}}$ (2013).Teachers' experience with inclusive education in Singapore.

11. Manguiob, Sharon Ross (2015). Reverse Inclusioin and the Learning Environment of Children with Special Needs. Unpublished Thesis.USEP, Davao City. Philippines.

12. Marland\& Osborne (1990).In the Teaching and teacher Education. Classroom Theory, Thinking and Action.

13. Piyao, Y. (2012). A Case Study of an early Childhood Educator in an Inclusive Classroom Setting.Unpublished Thesis, USEP, Davao City. Philippines.

14. Quijano, Yolanda S. (2011). Inclusive Education: The Philippine Perspective. Presentations for Vietnam.

15. Quijano, Yolanda S., et al (2007). Introduction to Special Education. Manila. Philippines.

16. Takahashi, J. (2013). Suggestions for a Teacher Training Program for Inclusive Education in a Japanese University.Creative Education, 4, 509-513. doi: 10.4236/ce.2013.48074. http://www.scirp.org/journal/PaperInformation.aspx?PaperID=35490\#.VbHMfbU6

17. Tornillo (1994).Concerns About and Arguments Against Inclusion and/or Full Inclusion. Retrieved: http://www.sedl.org/change/issues/issues43/concerns.html

18. DepEd Order No. 72, s. 2009, "Inclusive Education as Strategy for Increasing Participation Rate of Children. Retrieved: http://deped.gov.ph/orders/do-72-s-2009

19. DepEdOrder 50, s. 2014, "Guidelines on the Recruitment, Selection and Placement of Personnel Pursuant to the DepEd Rationalization Program Under Executive Order 366 s. 2004. Retrieved: http://www.deped.gov.ph/orders/

20. Indonesia's final National Report on Provision of Inclusive Education (4th draft).doc. Retrieved:http://www.ibe.unesco.org/fileadmin/user_upload/Inclusive_Education/Reports/ja karta_pecial Education Act of 2008, Article V, Sec 1 \&2, page 6-7.

21. UNESCO (2001).European Agency for Development in SpecialNeeds Education. Retrieved: www.european.agency.org

22. UNESCO (1994).Inclusive Education: Article 2: Salamanca Framework. Retrieved: http://www.unesco.org/education/sne/ 